\title{
A Case of Basal Cell Carcinoma with Outer Hair Follicle Sheath Differentiation
}

\author{
Masazumi Onishi Kazuhiro Takahashi Fumihiko Maeda \\ Toshihide Akasaka \\ Department of Dermatology, Iwate Medical University, Morioka, Japan
}

\section{Key Words}

Follicular differentiation - Solid-type basal cell carcinoma - Proliferating trichilemmal tumor . Infundibulocystic basal cell carcinoma

\begin{abstract}
A 70-year-old Japanese man presented at our hospital with an asymptomatic, blackish, irregularly shaped plaque with a gray nodule in the periphery on his left lower leg. The lesion had been present for 10 years and had recently enlarged, associated with bleeding. Histopathologically, the tumor consisted of three distinct parts: The first part showed massive aggregation of basophilic basaloid cells with peripheral palisading and abundant melanin granules, and was diagnosed as solid-type basal cell carcinoma. The second part showed aggregation of clear cells with squamous eddies, and was diagnosed as proliferating trichilemmal tumor. The third part showed reticular aggregation of basaloid cells with infundibular cysts in the papillary dermis, and was diagnosed as infundibulocystic basal cell carcinoma. We diagnosed this tumor as basal cell carcinoma with various forms of hair follicle differentiation, including differentiation into the outer root sheath.

\section{Case Presentation}

A 70-year-old Japanese man presented at our hospital with an asymptomatic, $20 \times$ $30 \mathrm{~mm}$ irregularly shaped blackish, flat elevated plaque with a gray nodule in the periphery on his left lower leg (fig. 1a). The lesion had been present for 10 years and had recently enlarged, associated with bleeding. He had a medical history of stenocardia, aortic stenosis and cerebral infarction. Dermoscopy revealed leaf-like areas, large blue-gray ovoid nests and

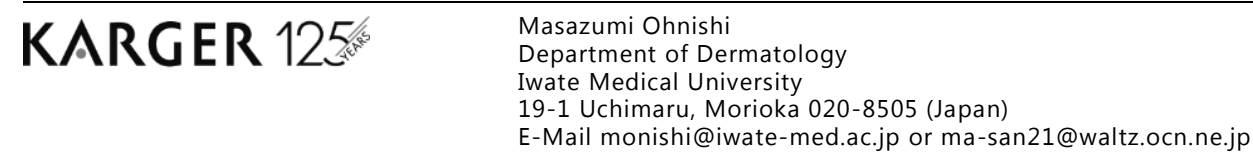


Case Reports in
Dermatology \begin{tabular}{l|l}
\hline Case Rep Dermatol 2015;7:352-357 \\
\hline DOI: 10.1159/000442704 & $\begin{array}{l}\text { ○ 2015 The Author(s). Published by S. Karger AG, Basel } \\
\text { www.karger.com/cde }\end{array}$ \\
\hline
\end{tabular}

Onishi et al.: A Case of Basal Cell Carcinoma with Outer Hair Follicle Sheath Differentiation

multiple blue-gray globules (fig. 1b). Basal cell carcinoma and malignant melanoma were listed as suspected diagnoses, and we performed an excisional biopsy of the tumor.

Histopathological examination of the tumor revealed infundibular structures of the outer hair sheath in the center of the plaque, which consisted of three distinct parts (fig. 2a). The first part showed circumscribed massive aggregation of basophilic basaloid cells containing abundant melanin granules with peripheral palisading and retraction spaces (fig. 2b). The second part showed aggregation of clear cells without nuclear atypia or mitosis. This part of the tumor exhibited trichilemmal keratinization with squamous eddies, which were surrounded by a fibrous stroma (fig. 2c). The third part showed reticular aggregation of basaloid cells with small infundibular cystic structures in the papillary dermis (fig. 2d). The stromal part showed no fibrosis and abundant mucin deposition staining positive with alcian blue (fig. 3a). Immunohistochemical staining revealed diffuse positivity for anti-bcl-2 in the first part (fig. 3b), positivity only at the periphery of tumor nests in the second part (fig. 3c), and diffuse positivity in the third part (fig. 3d). However, all parts of the tumor showed no staining for CK20 or BerEp4.

\section{Discussion}

Microscopic examination of the tumor showed that it consisted of three distinct histological types: massive aggregation of basophilic cells was diagnosed as solid-type basal cell carcinoma, massive aggregation of clear cells with trichilemmal keratinization was diagnosed as proliferating trichilemmal tumor, and reticular small aggregations of basophilic basaloid cells in the papillary dermis were diagnosed as infundibulocystic basal cell carcinoma.

Infundibulocystic basal cell carcinoma was first described as 'basal cell carcinoma with follicular differentiation' in 1987 by Tozawa and Ackerman [1], and later in 1990 the tumor was proposed as a variant of basal cell carcinoma showing differentiation to infundibular cyst-like structures by Walsh and Ackerman [2]. Clinically, the tumor presents as small papules/nodules, most commonly on the face. Characteristic histopathological features of the tumor are small symmetrical, circumscribed aggregations of basaloid cells containing numerous infundibular cyst-like structures. One of the differential diagnoses of infundibulocystic basal cell carcinoma is trichoepithelioma. Infundibulocystic basal cell carcinoma is different from trichoepithelioma in that there are no follicular bulbs and papillae, no stromal fibrosis around the tumor, reticulated pattern of neoplastic cells, and abundant epithelial mucin [2]. In the present case, anti-bcl-2 immunohistochemical staining was diffusely positive in portions of typical basal cell carcinoma and infundibulocystic basal cell carcinoma. Bcl-2 is a photo-oncogene related to programmed cell death [3]. In normal skin, bcl-2 is present within basal keratinocytes, mesenchymal cells of follicular papilla, clear cells of eccrine glands, melanocytes and lymphocytes [3]. Anti-bcl-2 staining is useful for distinguishing between trichoepitheliomas and basal cell carcinoma [4], the former staining positively in the periphery of tumor nests, whereas the latter shows diffuse and widespread staining in all tumor nests [5].

Basal cell carcinoma is a neoplasm proposed to be derived from epithelial germ cells, and infundibulocystic basal cell carcinoma is derived from the infundibulum of the hair follicle [6], whereas proliferating trichilemmal tumor is derived from the hair follicle isthmus [7]. There have been four reports of basal cell carcinoma arising with trichilemmoma without a pre-existing sebaceous nevus [8]. Taken together, the present findings suggest that 


\section{Case Reports in Dermatology}

\begin{tabular}{l|l}
\hline Case Rep Dermatol 2015;7:352-357 \\
\hline DOI: $10.1159 / 000442704$ & $\begin{array}{l}\text { (c) 2015 The Author(s). Published by S. Karger AG, Basel } \\
\text { www.karger.com/cde }\end{array}$ \\
\hline
\end{tabular}

Onishi et al.: A Case of Basal Cell Carcinoma with Outer Hair Follicle Sheath Differentiation

basal cell carcinoma may be derived from hair germ cells, including the outer hair sheath and hair follicular infundibulum.

\section{Statement of Ethics}

The authors state that the patient gave his informed consent.

\section{Disclosure Statement}

The authors report no conflicts of interest. There were no funding sources for this work.

\section{References}

1 Tozawa T, Ackerman AB: Basal cell carcinoma with follicular differentiation. Am J Dermatopathol 1987;9: 474-482.

-2 Walsh N, Ackerman AB: Infundibulocystic basal cell carcinoma: a newly described variant. Mod Pathol 1990;3:599-608.

-3 Córdoba A, Guerrero D, Larrinaga B, Iglesias ME, Arrechea MA, Yanguas JI: Bcl-2 and CD10 expression in the differential diagnosis of trichoblastoma, basal cell carcinoma, and basal cell carcinoma with follicular differentiation. Int J Dermatol 2009;48:713-717.

4 Smoller BR, Van de Rijn M, Lebrun D, Warnke RA: Bcl-2 expression reliably distinguishes trichoepitheliomas from basal cell carcinomas. Br J Dermatol 1994;131:28-31.

-5 Kloepper JE, Tiede S, Brinckmann J, Reinhardt DP, Meyer W, Faessler R, Paus R: Immunophenotyping of the human bulge region: the quest to define useful in situ markers for human epithelial hair follicle stem cells and their niche. Exp Dermatol 2008;17:592-609.

6 Roldán-Marín R, Leal-Osuna S, Lammoglia-Ordiales L, Toussaint-Caire S: Infundibulocystic basal cell carcinoma: dermoscopic findings and histologic correlation. Dermatol Pract Concept 2014;4:51-54.

-7 Satyaprakash AK, Sheehan DJ, Sangüeza OP: Proliferating trichilemmal tumors: a review of the literature. Dermatol Surg 2007;33:1102-1108.

8 Kaptan MA, Kattampallil J, Rosendahl C: Trichilemmoma in continuity with pigmented basal cell carcinoma; with dermatoscopy and dermatopathology. Dermatol Pract Concept 2015;5:57-59. 
Case Reports in
Dermatology

Case Rep Dermatol 2015;7:352-357

DOI: $10.1159 / 000442704$

(C) 2015 The Author(s). Published by S. Karger AG, Basel www.karger.com/cde

Onishi et al.: A Case of Basal Cell Carcinoma with Outer Hair Follicle Sheath Differentiation
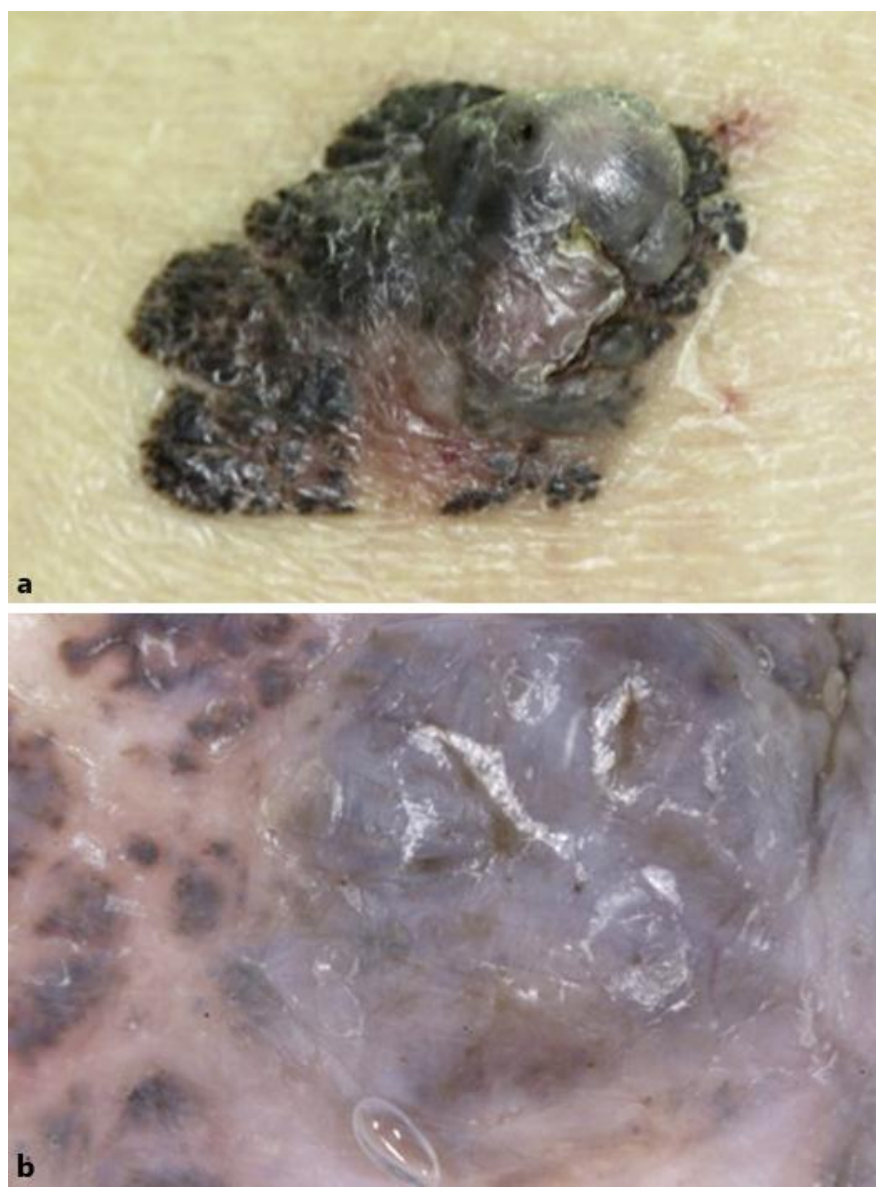

Fig. 1. a Clinical image. The tumor was asymmetric, flat and blackish-colored with a gray nodule. $\mathbf{b}$ The dermoscopic image revealed leaf-like areas, large blue-gray ovoid nests and multiple blue-gray globules. 
Onishi et al.: A Case of Basal Cell Carcinoma with Outer Hair Follicle Sheath Differentiation

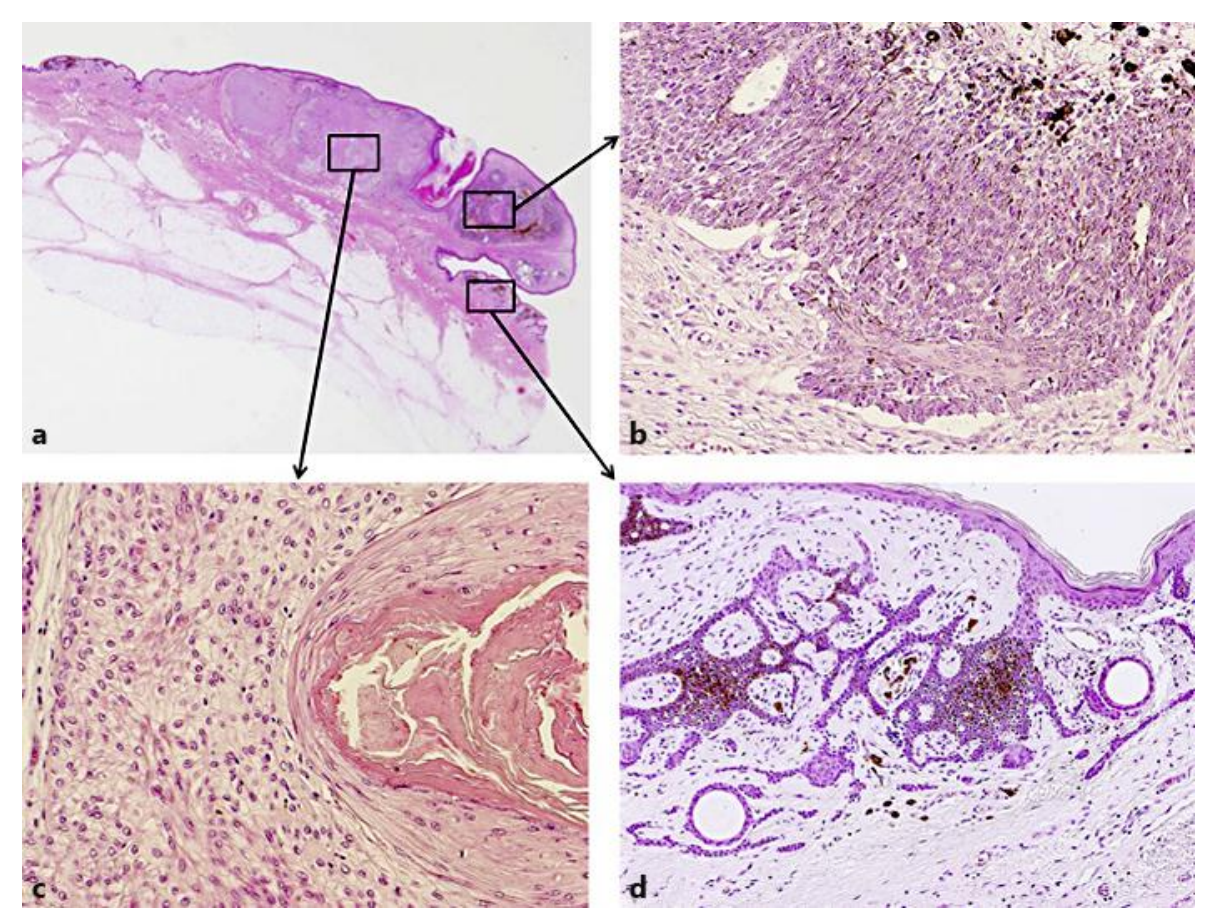

Fig. 2. a At low magnification, histopathological examination showed a well-circumscribed tumor consisting of three distinct parts and accompanied by a hair follicle in the center. $\mathbf{b}$ Massive aggregation of basophilic basaloid cells with peripheral palisading and retraction spaces around the tumor. c Massive aggregation of clear cells with squamous eddies exhibiting trichilemmal keratinization. $\mathbf{d}$ Reticular aggregation of basaloid cells with infundibular cysts in the papillary dermis. 
Onishi et al.: A Case of Basal Cell Carcinoma with Outer Hair Follicle Sheath Differentiation

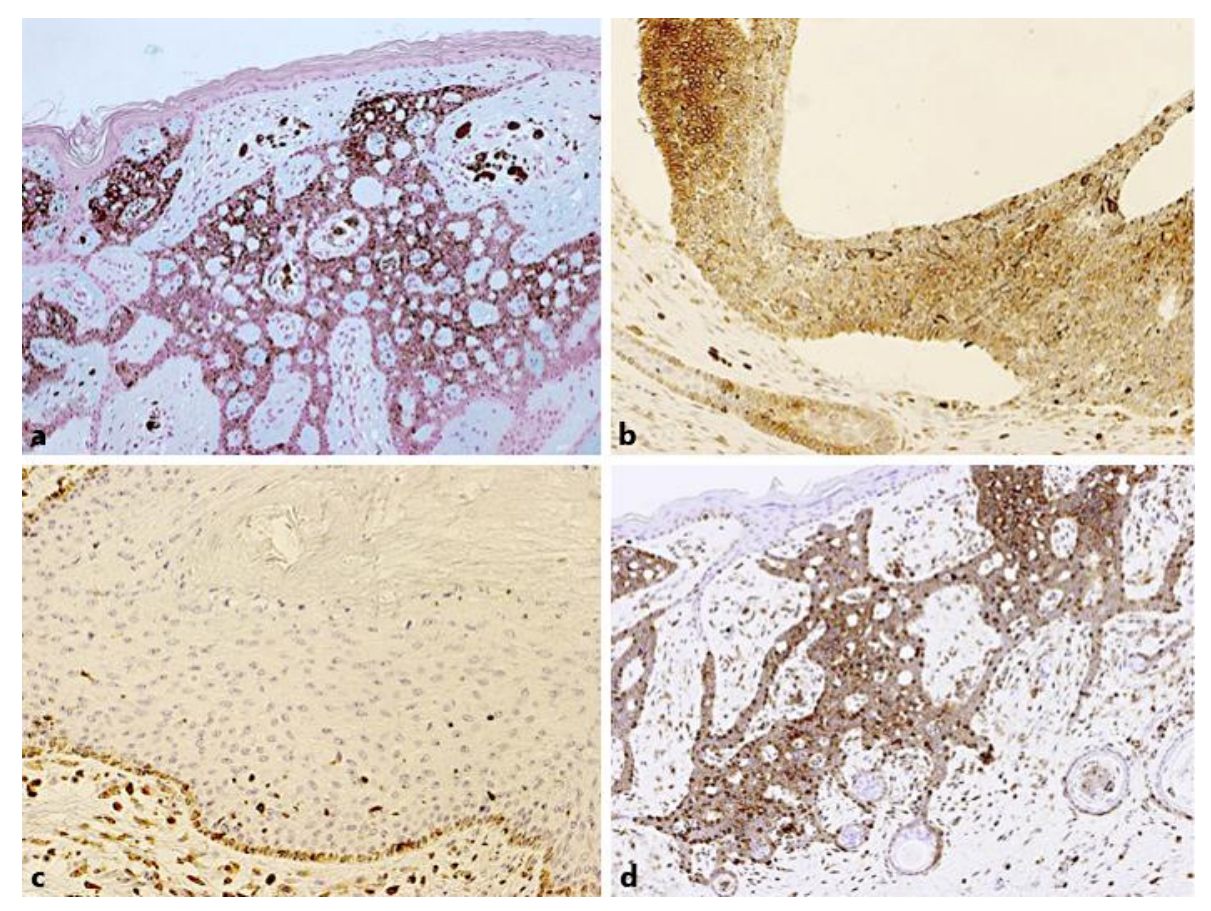

Fig. 3. a Alcian blue stain showed abundant mucin deposition in the stoma. b Massive aggregation of basophilic basaloid cells showing diffuse positive staining with anti-bcl-2 antibody. c Massive aggregation of clear cells staining positively only at the periphery of tumor nests with anti-bcl-2 antibody. d Reticular aggregation of basaloid cells showing diffuse positive staining with anti-bcl-2 antibody. 